Marquette University

e-Publications@Marquette

College of Education Faculty Research and

Publications

Education, College of

$2-6-2020$

\title{
Bonding and Bridging: An Equilibrium That Matters for Engaging Religious Diversity in a Pluralistic Society
}

\author{
Eboo Patel \\ Interfaith Youth Core \\ Benjamin Correia-Harker \\ Marquette University, ben.correia-harker@marquette.edu
}

Follow this and additional works at: https://epublications.marquette.edu/edu_fac

Part of the Education Commons

\section{Recommended Citation}

Patel, Eboo and Correia-Harker, Benjamin, "Bonding and Bridging: An Equilibrium That Matters for Engaging Religious Diversity in a Pluralistic Society" (2020). College of Education Faculty Research and Publications. 547.

https://epublications.marquette.edu/edu_fac/547 


\section{Bonding and Bridging: An Equilibrium That Matters for Engaging Religious Diversity in a Pluralistic Society}

Eboo Patel, Interfaith Youth Core

Benjamin P. Correia-Harker, Interfaith Youth Core

\section{ABSTRACT}

To effectively lead with our religiously diverse national and global communities, colleges and universities must engage practices and conditions that promote student interfaith learning and development. Recent research highlights seemingly divergent factors that both play significant roles to help prepare students for productive engagement across lines of religious and worldview difference. In this article, the authors explore why providing collegiate experiences that offer both spaces and opportunities for students to bond with others of like worldviews as well as bridge relationships across worldviews are important to civic health. They also discuss ways campus educators might incorporate these experiences and highlight a narrative that illustrates the importance of interfaith leadership and development.

Greg Damhorst grew up in a Midwest, middle-class suburb as a devout Evangelical Christian. His church happened to be directly adjacent to his diverse high school, so some church members came up with an idea to use the church's location to proselytize to the high school students - the church parking lot was a convenient location for school parking. Congregants figured they could restrict access to the church parking lot only to the students who expressed interest in getting to know Jesus. So each morning, a group of church members blocked off the entrance, providing access to some and turning away those who were not willing to consider Christianity as their faith.

As a believer and member of the church, Greg would regularly use the parking lot when going to school. Often, Greg would think of one of his Hindu friends, knowing that this friend would not be able to use the parking lot. He began to question if this action was the right way to invite others to his faith. If someone was open to learning about Jesus, they got the benefit of the parking lot, but if someone already had strong convictions in another belief system, then they were turned away. Greg began to question, would people express interest in Jesus just to get into the parking lot? Would students see this as a coercive tool by the church rather than an invitation to know Christ?

\footnotetext{
aboo Patel (eboo@ifyc.org) is founder and president of Interfaith Youth Core and author of Acts of Faith, Sacred Ground, Interfaith Leadership, and Out of Many Faiths.

${ }^{\mathrm{b}}$ Benjamin P. Correia-Harker (ben@ifyc.org) is director of assessment and research at Interfaith Youth Core and an Interfaith Diversity Experiences and Attitudes Longitudinal Survey (IDEALS) team member.
} 
Greg was a committed Christian and believed that Jesus was the only way to God, and yet something about this idea for proselytization did not sit well with him. He wanted to follow Jesus's example and be in right relationship with all of his neighbors, including those of other beliefs. For Greg, being in right relationship meant respecting others and understanding the need for cooperation across difference.

Upon entering college at the University of Illinois, Greg found the opportunity to deepen into his Evangelical faith and to continue to engage with people from different religious and spiritual worldviews. He joined both an Evangelical Christian association and a student group called Interfaith in Action, which brought students from different faith backgrounds together to talk about the disagreements and the commonalities across their traditions. In this way, Greg had a space that supported his own identity and a space that facilitated challenging yet productive encounters with people of different religious and spiritual worldviews.

In recent decades, growing numbers of citizens with different religious and secular beliefs, domestic incidents, such as $9 / 11$, that surfaced conversations about religion in civic spaces, and an interconnected global society have challenged the view that religion should be relegated to the margins of campus life. Increasingly, educators understand the importance of attending to students' religious and secular identities, and proactively educating for interfaith literacy and leadership (Jacobsen \& Jacobsen, 2012; Patel, 2018). After all, campuses are microcosms of our religiously diverse society, and students regularly encounter everything from various religious celebrations to hate incidents against specific religious groups to conflicts between values of different religious and secular communities. Educators can either allow such encounters to develop into mistrust and division, or they can skillfully guide students to see these interactions as opportunities to develop appreciation of others and bridge-building. To do the latter well, educators need to understand what contextual factors and practices help students develop toward these pluralistic ends.

The purpose of this article is to help educators create campus environments that nurture leaders like Greg Damhorst. In the next section, we will describe the Interfaith Diversity Experiences \& Attitudes Longitudinal Survey (IDEALS), a major survey of religious diversity in higher education. We will then highlight key findings of the survey, namely, the importance of both provocative encounters with worldview diversity and supportive spaces for spiritual expression. These are precisely the factors that played a key role in Greg Damhorst's development at the University of Illinois.

\section{IDEALS Overview}

The IDEALS project is a collaboration between North Carolina State University, the Ohio State University, and Interfaith Youth Core (IFYC), a nonprofit organization who partners with higher education institutions to promote interfaith cooperation and where the coauthors of this article work. Initiated in 2015, IDEALS tracks a cohort of students through their collegiate career and aims to better understand the climate factors, interfaith experiences, and pedagogical practices that influence student learning toward a range of pluralistic outcomes. The research design is based on Astin's (1991) inputs-environmentsoutcomes model in that the researchers captured student background information and perceptions related to key outcomes coming into college, curricular and cocurricular engagement as well as campus climate perceptions during college, and outcomes measurements again after four years of college. Thus, surveys 
were administered to students entering college, after their first year, and after the fourth year of college. For this article, we use data and analyses related to the first and second survey administrations.

IDEALS measures several interfaith learning and development outcomes that are necessary for productive civic engagement in our religiously diverse society: self-authored worldview commitment, pluralism orientation, appreciative knowledge, and appreciative attitudes toward others. Self-authored worldview commitment relates to students' degree of devotion to their own worldview (i.e., a guiding life philosophy that is based on a religious tradition, spiritual orientation, nonreligious perspective, or some combination of these; Mayhew et al., 2016). Infused with principles from Baxter Magolda's (2008) selfauthorship concept, self-authored worldview commitment accounts for students' awareness of other belief systems and intentional decision to commit to their own. Pluralism orientation is a multifaceted construct based on Eck's (2001) conception that includes an understanding of commonalities and differences between worldview, goodwill toward others of different worldviews, and a willingness to be in relationship with others of different worldview while maintaining a commitment to their own worldviews.

The last two outcomes of appreciative knowledge and appreciative attitudes toward others stem from the interfaith triangle, which is based on social science research by Putnam and Campbell (2010). The interfaith triangle theory posits that three interconnected factors influence the degree to which one develops an overall pluralistic orientation and, in turn, engages in interfaith cooperation: close relationships, appreciative attitudes, and appreciative knowledge (Patel, 2012). Close relationships are friendships with folks of other religious traditions or belief systems; appreciative attitudes represent a positive regard one has toward other religious and secular groups; and appreciative knowledge is familiarity with information about other traditions that supports a positive mind-set toward that group (Patel, 2012). These three aspects are mutually reinforcing force, so as one develops relationships, attitudes, or knowledge with or about other religious or secular individuals or traditions, then levels of the other aspects increase as well (Patel, 2012).

Thus, IDEALS captures these three interfaith triangle components with appreciative attitudes and appreciative knowledge being key outcome variables. Appreciative knowledge is represented by students' awareness of practices, beliefs, or figures related to a range of religious and secular traditions. As for appreciative attitudes, students responded to items pertaining to seven specific religious and secular groups (i.e., atheists, Buddhists, Evangelical Christians, Hindus, Jews, Muslims, and members of the Church of Jesus Christ of Latter-day Saints). For each group, students indicated the degree to which they thought people in each group contributed positively to society and were ethical people as well as to what degree the students felt they had something in common with and had a positive regard toward each group.

Although the IDEALS research team is in the nascent stages of the project, findings from students' first year of college point to important conditions and practices that seem to promote interfaith learning and development. The research team has published three reports that document behaviors and perceptions related to worldview diversity for incoming college students (Mayhew et al., 2016), overarching trends on student development associated with religious pluralism (Rockenbach et al., 2017), and specific practices that can spark growth in key outcomes (Rockenbach et al., 2018). From the latter two reports, IDEALS reveals promising trends, one of which is significant jumps in appreciative attitudes toward various worldview groups (Rockenbach et al., 2017). When exploring what factors contribute to these increases, two particularly potent variables surfaced: space for support and spiritual expression and provocative 
encounters with worldview diversity. It is on these two factors that we will focus, determining how we can make meaning of ways to best support student development toward positive civic engagement.

\section{Provocative Encounters With Worldview Diversity}

As one might expect, students who more frequently engaged in provocative encounters with worldview diversity also showed greater growth in interfaith learning outcomes during their first year of college (Rockenbach et al., 2018). Provocative encounters with worldview diversity are situations that disrupt how one typically understands the world; they are exchanges in which students realize new insights about others or themselves that do not fit with current ways they make meaning of particular religious or secular groups. The cognitive dissonance created requires students to either downplay new information, alter some of their conceptions, or completely dismantle and rebuild ways they think about various religious/ nonreligious groups and identities (Festinger, 1957). Provocative encounters spark the latter two cases and result in more complex and nuanced ways of thinking about other religious and secular communities.

Students who frequently engage in provocative encounters often report higher rates of growth in overall appreciative attitudes toward distinct groups in the first year of college; additionally, students who frequently have these challenging exchanges also tend to develop a deeper commitment to their own worldviews after their first year (Rockenbach et al., 2018). In essence, provocative encounters with worldview diversity seem to foster both advances in inter-group perceptions that till fertile ground for bridging with other worldviews and intra-personal mind-sets that inspire deeper understanding of religious and secular identities.

Educators can create provocative experiences through different curricular and cocurricular endeavors on campus. Provocative encounters can take place in the classroom when students engage in quality conversations about values or social issues related to course content, or meaningful conversations can surface from well-crafted discussion prompts at a coffeehouse or dinner program. Educators can manifest provocative experiences by attending to three issues: learning motivation by priming students to expect their perceptions of the world to be disrupted (and that that is ok); comprehension by assuring that content or encounters are accessible and developmentally appropriate; and metacognitive engagement by requiring students to reflect on the ways they think about the world (Dole \& Sinatra, 1998). When educators incorporate these practices into programs on worldview diversity, they can create optimal conditions for student learning.

\section{Space for Support and Spiritual Expression}

When exploring factors that seem to have the greatest impact on key interfaith learning outcomes, space for support and spiritual expression also surfaced as a valuable collegiate environmental factor (Rockenbach et al., 2017). Space for support and spiritual expression represents the degree to which students feel free to express their worldview identity in curricular and cocurricular spaces and perceive that faculty and staff accommodate their worldview holidays and observances. In their first year of college, students who viewed the campus as supportive of their worldview expression, no matter their religious or secular beliefs, tended to develop higher appreciative attitudes toward other worldview groups and a higher pluralistic orientations (Rockenbach et al., 2017). When looking at particular aspects of this concept, all four items that compose the space for support and spiritual expression scale were top 10 predictors for both outcomes (Rockenbach et al., 
2018). Thus, each distinct component supporting worldview expression matters, one aspect of which is offering a place or group for specific religious or secular communities to bond just as Greg had with the Evangelical Christian association. Educators should focus on providing and advertising religious accommodations, assuring students of different worldviews have distinct places on campus where they can express their identities (e.g., student groups, places of worship), and cultivating curricular and cocurricular spaces that are supportive of worldview expression.

This may seem counterintuitive to some in that space for support and spiritual expression is not about engaging worldview difference; instead it focuses on students' living out their own belief systems on campus. However, as students feel assured in their own religious and secular identities, they may be more willing to step outside of their comfort zone and seek understanding across difference. Contact and interaction with people who are different from oneself can be anxiety-inducing, and yet many political philosophers argue that a key quality of citizens who live in a diverse democracy is the ability to constructively engage with reasonable disagreement (Stout, 2005).

Students may feel insecure about how to appropriately engage or how to navigate conversations in which students may disagree with the other person. Sometimes disagreement across lines of difference may not feel threatening, and other times, constructively engaging with others who hold antagonistic or theologically exclusive beliefs may feel deeply challenging. Here too, the expectation of "reasonable disagreement" may include viewpoints which fundamentally diverge and conflict with one's own. This type of disagreement is important to learn to navigate as a civic skill, while maintaining a fundamental expectation that respect for identity and humanization of the other is at the heart of the exchange. When students are supported in their worldviews, they may feel centred within their identities, providing them with the courage to immerse themselves in unfamiliar experiences and open themselves up to thoughts and ideas that deviate from their own. Space for support and spiritual expression may foster developmental processes that enable students to make connections with and develop a positive general regard toward others.

Providing this type of support and space on college campuses can range from policies and physical accommodations to networks or communities who represent different worldview constituents. According to a recent inventory of interfaith practices at colleges and universities, approximately $98 \%$ of campuses reported they provide some form of accommodations for students' worldview expression (Interfaith Youth Core [IFYC], 2017). This is promising! College and universities are paying attention to accessible dining and reasonable housing accommodations for students of distinct worldviews as well as supporting space needs and student groups that serve distinct religious and secular communities. Unfortunately, the types of accommodations that institutions provide for different worldviews vary, with some worldviews receiving less support. Only 5\% of campuses said they had a space for an intentionally secular community (IFYC, 2017). At one religiously affiliated institution, students struggled to receive approval to form a secular student group on campus. Furthermore, less than a quarter of the campuses reported having procedures to regularly review and update accommodation policies for ever-changing student populations (IFYC, 2017). With space for support and spiritual expression being a critical factor for interfaith learning and development, educators have room to grow to meet a diverse range of student worldview needs.

\section{Finding an Equilibrium}

What is interesting about the two factors discussed is that space for support and spiritual expression and provocative encounters with worldview diversity may seem to be at odds with each other. Educators may 
feel tension as to how successfully attend to both factors on their campuses. Providing a supportive environment for students to express their worldviews means carving out time and space for students to be in community with those who share their belief systems, while provocative encounters require educators to orchestrate conditions and places for students to productively engage across different groups. Campuses must seek out an appropriate balance of resources and time for these two practices to provide students with an optimal environment for interfaith learning. Traversing diverse perspectives by balancing tensions is paralleled in other conceptual frameworks that explore living in diverse civic spaces. Putnam (2000) differentiated forms of social capital (i.e., strong levels of interpersonal trust within extensive networks) into bridging and bonding capital, both of which are necessary in a diverse civic space. Bonding capital is formed within groups whereas bridging capital is built between groups. Whereas bonding provides strong social supports that help individuals cope with life experiences, bridging is theorized to build generalized trust in a broader community (Marshall \& Stolle, 2004; Putnam, 2000). This trust is needed to maintain and strengthen the fabric of a pluralistic society. As students are supported to express their worldviews as part of religious or secular communities and challenged to interact in meaningful ways across worldview communities, they fortify the campus community and learn how to effectively balance both for life as engaged citizens.

\section{Conclusion}

We opened this article with the story of Greg Damhorst, and how his experience at the University of Illinois was crucial to his development as a person and his experience as a student. The campus environment at the University of Illinois had groups that both supported Greg's Evangelical Christian identity (i.e., space for support and spiritual expression) and facilitated meaningful engagement with students from different faith backgrounds (i.e., provocative encounters with worldview diversity). We want to end with a story that highlights how the balance of these bonding and bridging opportunities was not only crucial for Greg's own personal development but also nurtured exceptional interfaith leadership skills.

Based in part on his experiences in his Evangelical Christian group, Greg helped the leaders of Interfaith in Action organize an annual "Day of Interfaith Service." Interfaith in Action leaders, including Greg, set up volunteer sites, recruited participants from different student religious groups, organized them into religiously diverse groups, and facilitated small group discussions about the shared value of service across faiths.

Involvement remained modest for several years, but the network of relationships that Interfaith in Action cultivated were increasingly impressive. Directors of local social service agencies came to respect Greg and his colleagues and rely on the annual volunteer day. Leaders of various religious student organizations encouraged their members to participate in the days of service, resulting in markedly lower tension between religious communities across the campus. Personally, Greg felt fulfilled. The model of discussing shared values like mercy and compassion with people of different traditions and applying those values in interfaith service projects, allowed him to speak openly about his Christian inspiration while also listening respectfully to others.

In January of 2010, a catastrophic earthquake hit Haiti, killing tens of thousands of people and leaving a million homeless. Greg and the executive committee of Interfaith in Action (which included a Catholic, a Buddhist, a Hindu, and a Humanist) quickly organized. They found the most practical way 
they could help - packing nutritious, dry-goods meals - and set a goal for the University of Illinois and the Champaign-Urbana community to pack one million meals for Haiti in a weekend. Their bridging and bonding capital helped mobilize their network among student groups and between community religious organizations; local social service agencies helped them find space and a federal grant to support the event. In a 12-hour period, over 5,000 people packaged more than a million meals for Haiti. At the event, they posted butcher paper on a wall so people could write what inspired them to serve. Hundreds took the time to leave a quote about service from their tradition on the wall. Greg wrote down a line from the Bible and felt deeply moved by the quotes from other sacred scriptures. His grounding in his Evangelical Christian faith and experiences engaging in meaningful conversation with others of different beliefs enabled Greg to effectively perform his civic duty and answer the call of a community in need.

\section{References}

Astin, A. W. (1991). Assessment for excellence: The philosophy and practice of assessment and evaluation in higher education. Washington, DC: American Council on Education/Oryx Press Series on Higher Education.

Baxter Magolda, M. B. (2008). Three elements of self-authorship. Journal of College Student Development, 49, $269-284$. doi:10.1353/csd.0.0016

Dole, J. A., \& Sinatra, G. M. (1998). Reconceptualizing change in the cognitive construction of knowledge. Educational Psychologist, 33(2/3), 109-123. doi:10.1080/00461520.1998.9653294

Eck, D. L. (2001). A new religious America: How a "Christian country" has become the world's most religiously diverse nation. New York, NY: HarperCollins.

Festinger, L. (1957). A theory of cognitive dissonance. Stanford, CA: Stanford University Press.

Interfaith Youth Core. (2017). Engaging religious and worldview diversity: A snapshot of promising practices at U.S. colleges and universities. Chicago, IL: Author.

Jacobsen, D., \& Jacobsen, R. H. (2012). No longer invisible: Religion in university education. New York, NY: Oxford University Press.

Marshall M. J., \& Stolle, D. (2004). Race and the city: Neighborhood context and the development of generalized trust. Political Behavior, 26, 125-153.

Mayhew, M. J., Rockenbach, A. N., Correia, B. P., Crandall, R. E., Lo, M. A., \& Associates. (2016). Emerging interfaith trends: What college students are saying about religion in 2016. Chicago, IL: Interfaith Youth Core.

Patel, E. (2012). Sacred ground: Pluralism, prejudice, and the promise of America. Boston, MA: Beacon Press.

Patel, E. (2018). Out of many faiths: Religious diversity and the American promise. Princeton, NJ: Princeton University Press.

Putnam, R. D. (2000). Bowling alone: The collapse and revival of American community. New York, NY: Simon \& Schuster Paperbacks.

Putnam, R. D., \& Campbell, D. E. (2010). American grace: How religion divides and unites us. New York, NY: Simon \& Schuster.

Rockenbach, A. N., Mayhew, M. J., Correia-Harker, B. P., Dahl, L., Morin, S., \& Associates. (2017). Navigating Pluralism: How students approach religious difference and interfaith engagement in their first year of college. Chicago, IL: Interfaith Youth Core.

Rockenbach, A. N., Mayhew, M. J., Correia-Harker, B. P., Morin, S., Dahl, L., \& Associates. (2018). Best practices for interfaith learning and development in the first year of college. Chicago, IL: Interfaith Youth Core.

Stout, J. (2005). Democracy \& tradition. Princeton, NJ: Princeton University Press.

doi:https://doi.org/10.1080/2194587X.2019.1696833

http://journals.naspa.org/jcc

(c) NASPA 2020

JCC 